\title{
Royal Images and Coronation Celebrations in the Sermons of Yovhannēs Pluz Erznkac'i
}

\author{
Gohar Grigoryan Savary
}

In 2013, the Matenadaran Institute of Ancient Manuscripts published the longawaited volume of the speeches and sermons of Yovhannēs Pluz Erznkac'i (i.e. from Erznkay, present-day Erzincan, Turkey), one of the most illustrious Armenian authors of the $13^{\text {th }}$ century. ${ }^{1}$ Prepared by two devoted scholars of Erznkac'i, the late Armenuhi Ter-Srapyan and the late Edvard Baghdasaryan, this publication represents the first volume of what will be a series of publications of Erznkac'i's works, offering the first edition of many homilies, sermons and speeches delivered by Erznkac'i in various cities of Cilicia and Greater Armenia, as well as in Jerusalem and T'iflis (Tbilisi).

This paper presents a translation of select chapters from Sermons 1, 8, 10, 29, and $30,{ }^{2}$ in which Erznkac'i uses the specific subjects of royal images and urban feasts for comparative and exegetical purposes. Although the author does not specify his sources - and, in fact, mentions these two subjects in figurative language aimed at enhancing and better explaining the principal themes of his speeches - one can detect in these 13th-century writings many elements of aesthetic thinking with an origin in the Greek milieu. The selected excerpts will show that Erznkac'i was a bearer of the Platonic concept of the archetype and its image, which likely entered his writings through the works of previous Armenian authors and Church Fathers. Particularly influential for Erznkac'i's aesthetic reflections seem to be the Cappadocian Fathers - or "great

1 Yovhannēs Erznkac'i (Hovhannes Yerzynkatsi), Matenagrut'iwn, hator A. Čarer ew k'arozner [Works, volume I - Speeches and Sermons], eds. Armenuhi Yerzynkatsi-Ter-Srapian, and Edvard Baghdasaryan (Yerevan, 2013). Throughout this essay, Armenian letters are transliterated according to the Hübschmann-Meillet-Benveniste system. To indicate the collections of Armenian manuscripts, I follow Bernard Coulie's system of acronyms as given in his Répertoire des manuscrits arméniens. Liste des sigles utilisés pour désigner les manuscrits (Association Internationale des Études Arméniennes): M = Yerevan, Matenadaran - Mesrop Maštoc' Institute of Ancient Manuscripts, and J = Jerusalem, Armenian Patriarchate.

2 In the cited edition from 2013, the text of Sermon 1 is based on the manuscripts M2173, M2992, and M2854. Sermons 8 and 10 are based on M2173 and M2854, Sermon 29 on M2173 and M7032, and Sermon 30 on M2173 and M218. 
Cappadocians," as they are known within the Armenian tradition - whose importance in the formation of the Christology of the Armenian Church has long been acknowledged in scholarship. Although the references that accompany my English translations reveal some of the sources Erznkac'i made use of, I am not concerned here with detailing the roots of his philosophical and theological formation - a topic still in need of study yet requiring a more extended format than this limited paper affords. My interest in this 13th-century author lies elsewhere. When speaking of royal images and other royal customs in front of an Armenian audience consisting of kings, aristocrats, high clergy, and ordinary people, Erznkac'i - whether in an indirect or direct way - must have instructed them about how to see contemporary royal images, many of which were created according to those aesthetic approaches he frequently points at. In this sense, Erznkac'i positions himself not only as transmitter of centuriesold aesthetic knowledge but also as practitioner of that knowledge. Addressing his sermons and homilies to an audience of people who in their own time were beholders of artistic images, he edified and guided them in how to perceive those images.

Although frequently invoked in his exegetical preaching, the reception of royal images is not, in itself, Erznkac'i's focus. He often uses examples involving artistic portraiture as a means of explaining the principle of the imitation of God, which was of particular relevance to kings, since they were considered to be the earthly counterparts of Christ, the Heavenly King. This analogy - omnipresent in many medieval Christian societies - shaped also Cilician Armenian political theology, to which Erznkac'i himself greatly contributed. ${ }^{3}$ The politics of Cilician royal portraiture reflected this theology in many ways. Therefore, the below-translated excerpts from Erznkac'i's sermons may disclose something useful about the philosophical and theological grounds of artistic practices in medieval Armenia.

Before proceeding to the translated passages, a few words should be said about Erznkaci's audiences, as well as about the contents and contexts of the selected sermons. At least three of them $(1,8$, and 10) were composed in Cilician Armenia. Sermon 1, consisting of 15 chapters, is the author's commentary on Psalm 140 and was read in "the famous and great hermitage of Drazark." ${ }^{4}$ Sermon 8 , consisting of 38 chapters, was composed on the occasion

3 Peter S. Cowe, "Theology of Kingship in 13th-Century Armenian Cilicia," Hask hayagitakan taregirk' 11 (2007-2008), pp. 417-430.

4 Erznkac'i, Speeches and Sermons, pp. 34-53. Previously published in:Edvard Baghdasaryan, and Mesrop Aramean, "Yovhannēs Erznkac'u I ČX satmosn čaṙ,," [Yovhannēs Erznkac'i's Sermon On Psalm 140] Gandzasar 7 (2002), 384-408. See also (for fragmentary citations from M2173): Edvard Baghdasaryan, "Hovhannes Erznkac'in arvesti u azgagrut'yan 
of the feast of the Nativity and was publicly read in Sis, the capital of Cilician Armenia. ${ }^{5}$ And finally, the 59 chapters of Sermon 10 comment on Psalm 138:6 ("Such knowledge is too wonderful for me"). ${ }^{6}$ Apart from being a thorough biblical commentary, this sermon is an explicit representation of the Christology of the Armenian Apostolic Church, as aspect highlighted especially in its second part (see e.g. chapters 35-39). Erznkac'i delivered this sermon in Anawarza (alternatively spelled Anarzaba) in the presence and most likely at the invitation of the archbishop Grigor, who years later became Catholicos Grigor VII Anawarzec'i (1293-1307) and was the main initiator of the controversial Council of Sis (1307). ${ }^{7}$ In two other sermons selected for this paper (29 and 30), the exact location where they were delivered is not mentioned. Sermon 29 is preserved in 46 chapters and presents Erznkac'i's commentary on Wisdom 2:23 ("God created man incorruptible and made him according to His own munificent image," translating the verse as it appears in Erznkac'i's text). ${ }^{8}$ Sermon 30 was composed at the request of a vardapet (church scholar, teacher) from Surb Karapet Church, whose name, unfortunately, appears effaced in the manuscript. It consists of 35 chapters, in which Erznkac'i comments on John 10:11 and 14 ("I am the good shepherd"). ${ }^{9}$

masin," [Yovhannēs Erznkac'i on Art and Ethnography] Lraber hasarakakan gitut'yunneri [Herald of the Social Sciences / Armenian National Academy of Sciences] 9 (1971), 75; Armenuhi Srapyan, "Hovhannes Erznkac'u gełagitakan hayac'k'nerə," [Yovhannēs Erznkac'i's Aesthetic Thoughts] Patma-Banasirakan handes [Historical-Philological Journal] 3 (1985), 103; Ead., "Arvesti əmbinumə Hovhannes Erznkac'u gorcerum," [The Perception of Art in Yovhannēs Erznkac'i's Works] Banber Erewani hamalsarani [Bulletin of Yerevan University] 2/65 (1988), 133.

5 Erznkac'i, Speeches and Sermons, pp. 122-46.

6 Ibid., pp. 167-206. See also (for fragmentary citations from M2173): Srapyan, "Hovhannes Erznkac'u gełagitakan hayac'k'nerə," p. 103; Ead., "Arvesti əmbrinumə," p. 135.

7 As shown by his later activities and especially by the initiation of the Council of Sis, the future catholicos's doctrinal orientation was at odds with the Christology of the Armenian Church. In this regard, Erznkac'i's preaching activities in Anawarza and the praise and promotion of the Armenian Church's Christology seem to have been incompatible with the vision of Anawarza's archbishop and later catholicos Grigor, who is often represented as a latinophile. Taking this evidence into account, Baghdasaryan suggested that Erznkac'i must have visited Anawarza and read this sermon during the reign of King Lewon II (1270/ 71-1289) (see Baghdasaryan's comments in: Erznkac'i, Speeches and Sermons, pp. 167-8), for it was after Lewon's death and with the succession of the Franciscan king Het'um II (1289-1307, intermittently) that the debates on union with Rome became more insistent within the Armenian Church and the royal court.

8 Ibid., pp. 501-19. See also: Srapyan, "Arvesti əmbrinumə," p. 134.

9 Erznkac'i, Speeches and Sermons, pp. 520-44. See also (for fragmentary citations from M2173): Srapyan, "Arvesti əmbrinumə," p. 134; Lewon Xačikyan, "Hay arvesti patmut'yan karewor skzbnałbyurnerə," [Important Primary Sources for Armenian Art History] in The Second International Symposium on Armenian Art, Yerevan, 12-18 September 1978, Collection 
Also preserved are several other sermons - not discussed here - that Erznkac'i delivered during his stay in Cilicia, as for instance, Sermon 9, delivered at the solemn knighting ceremony (1283) of the princes Het'um and T'oros, sons of Lewon II. ${ }^{10}$ Erznkac'i was hosted at the Cilician court at least twice, the second time on his way to Jerusalem. Based on some fragmentary details available in textual sources, Baghdasaryan has established that he must have died in 1293 in the Cilician monastery of Akner, later to be reburied in his native Erznkay. ${ }^{11}$ His visits and preaching activities in important Cilician centres speak to the authority enjoyed by the Erznkay vardapet, which inspired the royal family and high clergy to entrust him with the composition of solemn speeches for significant religious and military feasts. ${ }^{12}$

of Reports, 4 (Yerevan, 1981), p. 42; Sirarpie Der Nersessian, Miniature Painting in the Armenian Kingdom of Cilicia from the Twelfth to the Fourteenth Century, vol. 1 (Washington, D.C., 1993), p. 154 (English translation based on Xačikyan's fragmentary citation from M2173).

10 Erznkac'i, Speeches and Sermons, pp. 147-66. On this sermon, see also: Edvard Baghdasaryan, "Hovhannes Erznkac'in Kilikiayi zinvorakan kazmakerput'yunneri masin," [Yovhannēs Erznkac'i on the Military Organizations of Cilicia] Banber Matenadarani [Bulletin of Matenadaran] 16 (1994), 44-57; Cowe, "Theology of Kingship," pp. 422-3.

11 For Erznkac'i's travels to Cilicia and his death, see: Edvard Baghdasaryan, Hovhannes Erznkac'in yev nra xratakan arjaka [Hovhannes Erznkac'i and His Advice Literature] (Yerevan, 1977), pp. 25-34; Baghdasaryan's Introduction to Erznkac'i, Speeches and Sermons, pp. 22-8. See also: Armenuhi Yerzynkatsi-Srapian, Hovhannes Erznkac'i Pluz: Kyank's ew gorca [The Life and Work of Hohannes Erznkaci Pluz] (Yerevan, 1993), pp. 38-9; Seta B. Dadoyan, "Yovhannēs Erznkac'i Bluz," in Christian-Muslim Relations: A Bibliographical History, 4 (1200-1350), eds. David Thomas, and Alex Mallett (Leiden, 2012), pp. $572-3$.

12 The sermons are not the only written products left from Erznkac'i's activities in Cilicia. The idea for his Compilation of Commentary on Grammar had also emerged as a result of his Cilician sojourn in the first half of the $128 \mathrm{os}$, when he was asked by catholicos Yakob Klayec'i to teach grammar at local monasteries. This work was completed in 1291 in the Surb Minas Monastery of Erznkay. See: Roberta Ervine, "Yovhannēs Erznkac'i Pluz's Compilation of Commentary on Grammar as a Starting Point for the Study of Medieval Grammars," in New Approaches to Medieval Armenian Language and Literature, ed. Jos Johannes Sicco Weitenberg (Amsterdam, 1995), pp. 149-66; Baghdasaryan, Hovhannes Erznkac'in, p. 27. Apart from this, Erznkac'i prepared an abbreviation of his famous Xrat hasarakac' k'ristonēic' (Instruction for All Christians), whose longer version was initially composed in Erznkay. Preserved in two main versions and in a few hundred copies a sign of its continuous popularity within Armenian society - this remarkable piece of medieval advice literature is addressed to both the religious and secular classes, aiming to regulate various aspects of their spiritual and religious life. For the text of Xrat hasarakac', see: Baghdasaryan, Hovhannes Erznkac'in, pp. 139-201, also pp. 48-61. In this publication, the scholar is unsure about the Cilician origins of the abbreviated version of the Xrat hasarakac', whereas in his latest study he suggested that it was written in Cilicia. See Baghdasaryan's comments in: Erznkac'i, Speeches and Sermons, p. 22, n. 35. 


\section{Sermon 8, chapter 1}

Sermon 8. Yovhannēs vardapet E(r)znkayec'i's [sermon] on the feast of the Christ's birth and baptism, delivered at the public celebration in the royal residence city of Sis. ${ }^{13}$

Chapter 1.... We can also witness that the laws of the sovereigns are so arranged that when a new sovereign king occupies the kingdom's throne and sends the royal order's decree into the country, amid the cities' huge crowds of people and in numerous buildings of the streets, the good news is announced, and everyone rejoices; and various festivities fill all the squares of the city, decorating the streets with linen covers painted with all manner of flowers, with branches of trees and flowers; and with the beauty of delicious fruits every door and shop is made resplendent. And various craftsmen hurry to decorate the streets, each with his own art. And thus, they express the joy of their hearts in public view.

With this description of how cities were decorated to celebrate the enthronement of a new king, Erznkac'i begins Sermon 8, which, as mentioned, was delivered during the celebration of the feast of the Nativity in the capital Sis. He then continues his speech by saying that if people rejoice for the glory of an earthly king in such a festive manner, how much more should they rejoice for the feasts of the Lord, especially on the day of Christ's birth, baptism, and epiphany (which in the Armenian tradition are celebrated together on 6 January). In composing his Nativity sermon to be delivered in front of the Sis public, it was not by chance that Erznkac'i began with the description of coronation celebrations, for new kings were usually crowned on the very feast of the Epiphany, thus imitating the appearance of Christ, the Heavenly and Eternal King. The tradition of crowning the king on the day of Christ's birth was

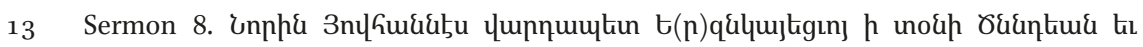

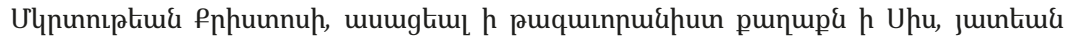
unokumuñpnıtiud.

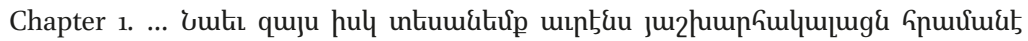

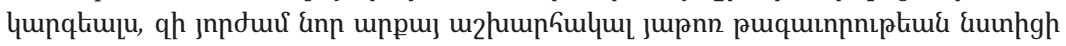

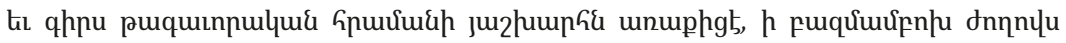

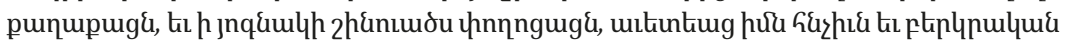

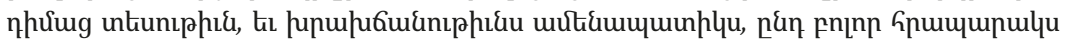

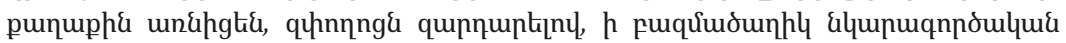

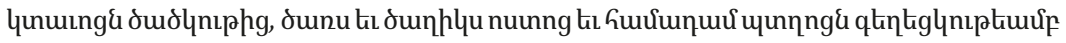

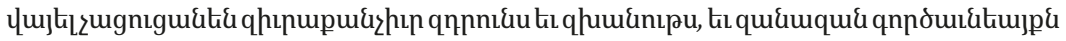

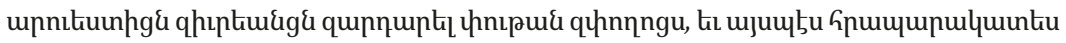
qnıpu|unıphıd ununhgd unfihgtid. Erznkac'i, Speeches and Sermons, pp. 122-46, esp. 123. 
especially common in the case of kings who had founded a dynasty or state, ${ }^{14}$ with the newly crowned monarch being paralleled with Christ, his model. In Cilician Armenia, the coronations of at least three kings took place on the day of Christ's birth and epiphany: the founder King Lewon I (1198, Tarsus), Lewon II (1271, Tarsus), and Smbat (1297, Sis). Erznkac'i, who was hosted at the court of Lewon II in Sis, delivered his sermon in front of an audience that must have included many who had been present for Lewon's coronation earlier in 1271.

\section{Sermon 10, chapter 9, and other texts}

Sermon 10. On the prophet David's "Such knowledge is too wonderful for me" [Psalm 138:6], delivered by Yohanēs vardapet E[r]znkayec'i in Anawarza to the bishop and vardapet Grigor. ${ }^{15}$

Chapter 9. And then he [David] said: "Such knowledge is too wonderful for me." What I desire and wish for is to attain Your knowledge, which

14 In the West, this was the case, for example, for Charlemagne (80o) and Roger II of Sicily (1130); in the Byzantine Empire, for Michael II the Amorian (820) and Constantine X Doukas (1059).

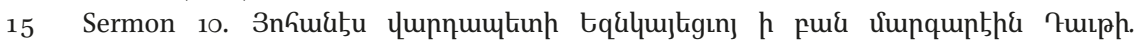

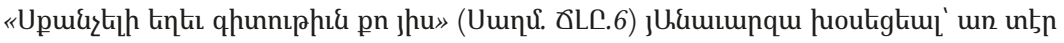

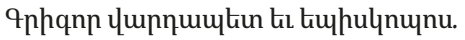

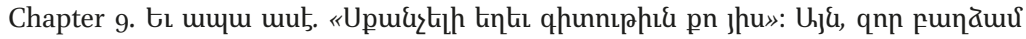

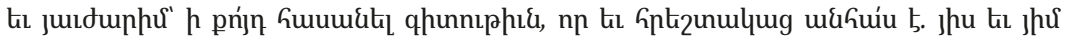

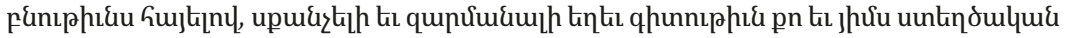

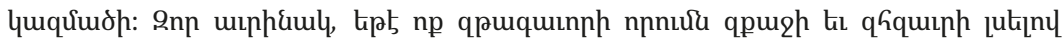

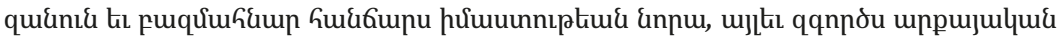

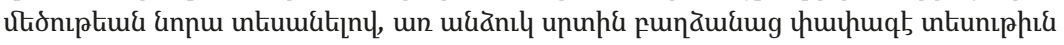

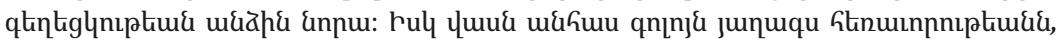

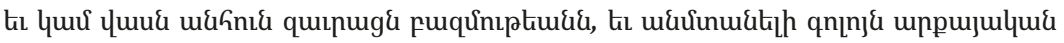

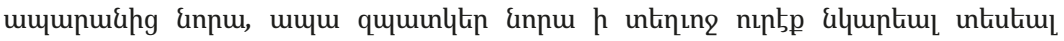

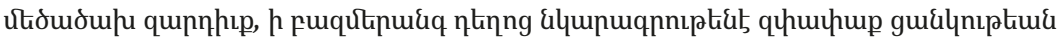

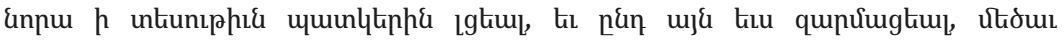

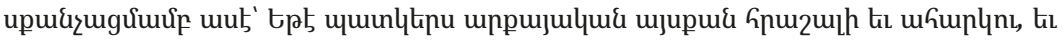

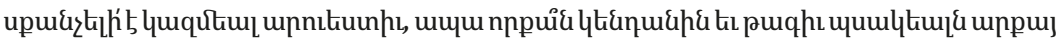

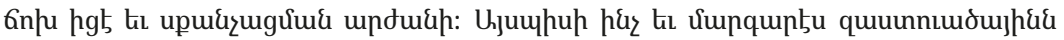

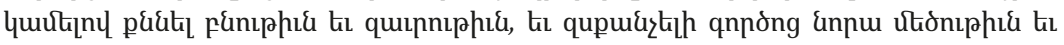

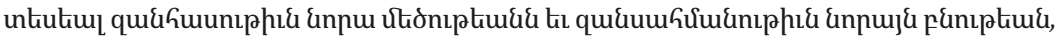

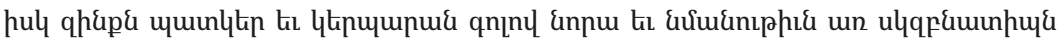

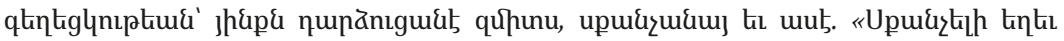

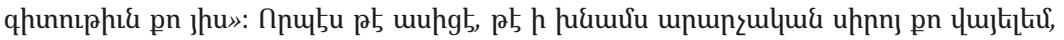

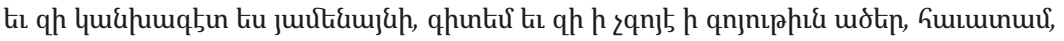

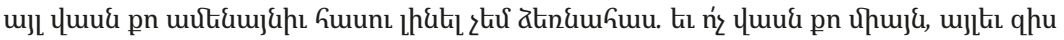

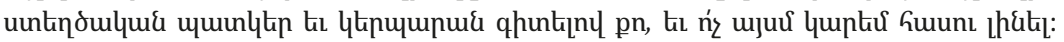


is unattainable even for angels. To me and my nature, wonderful and astonishing is the knowledge of You and of my Created form. As, for example, when someone hears the name of a valiant and mighty king and the multiple qualities of his wisdom and sees the royal deeds of his greatness, (s)he heartfully desires to see the beauty of his person. But because this is unattainable whether due to the distance or the immense multitude of the [king's] troops and the impossibility of entering his royal palace, then when (s)he sees the king's painted image adorned with costly decorations in a certain place, (his) her desire is filled by the vision of that image pictured in multicolour paints, and then (s)he marvels at that, saying with great fascination: "If the royal image is so wonderful and terrific and is so marvellously executed in art, then how much more magnificent and worthy of admiration must the real and crowned king be?!"16 In such a way, also the prophet, wishing to search out the nature and power of the Divine and the greatness of His wonderful deeds, and seeing the inaccessibility of His greatness and the infinity of His nature - and he himself being only created in His image and in His appearance and merely reflecting the likeness of the beauty of the archetype - turned his thought into wonder, saying: "Such knowledge is too wonderful for me." And, behold, I enjoy Your Creative love; and because You know everything in advance and because out of non-existence you led [all things] into existence, I believe, although I am

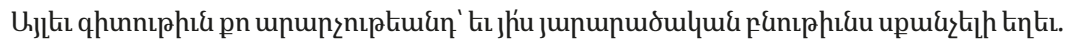
Erznkac'i, Speeches and Sermons, pp. 167-206, esp. 172.

16 Cf. the homily of Severian of Gabala on the Holy Cross, quoted by Vrt'anes K'ert'ol in his famous 7 th-century treatise against the iconoclasts: "Et l'évêque Sévérien dit: Lorsque le roi est absent et son portrait occupe la place du roi, les princes se prosternent et célèbrent les fêtes; si des paysans le voient ils se prosternent également, considérant non pas le bois mais le portrait du roi; ils ne considèrent pas la substance mais ce qui est tracé par la plume. Et si le portrait du roi mortel prend ainsi une telle puissance, combien plus la forme et l'image du roi immortel." See: Sirarpie Der Nersessian, "Une apologie des images du septième siècle," Byzantion 17 (1944-1945), 61. The same passage from Severian of Gabala's homily is quoted by John of Damascus in his Third Treatise in defense of images (which, however, seems to have never been translated into Armenian but might be known to Armenian authors): "For if the image of an absent Emperor fulfils the place of the Emperor, and rulers venerate it, and sacred festivals are celebrated before it, and rulers meet it, and the people venerate it, not looking at the wooden plank, but at the figure of the Emperor, who is not seen to be present by nature, but is depicted by art, how much more is the image of the immortal Emperor able, not only to strike stone, but the heaven and the whole earth?". See: Saint John of Damascus, Three Treatises on the Divine Images, translation and introduction by Andrew Louth (New York, 2003), p. 15 o. 
unable to comprehend all things of Yours. And not only all things of Yours, but I am even unable to attain the knowledge of myself as created in Your image and form. Rather, the knowledge of Your Creation, even of my Creaturely nature, is too wonderful [for me].

This quotation is taken from Erznkac'i's picturesque tenth sermon which, as mentioned in its title, is the theologian's commentary on the psalmist's words "Such knowledge is too wonderful for me". In an indirect way, Erznkac'i provides his Anawarza audience with a mode of perception of royal images. That mode proceeds from the assumption that the "wonderful and terrific" royal image is a substitute for the king's physical presence - albeit never a perfect, equal substitute. The inferior, imitative status assigned to the royal image, along with the impossibility of gaining access to see the king in person, enhanced the viewer's fascination with and admiration of him. Erznkac'i parallels the unfulfillable desire to personally see the mighty and wise king with the inaccessibility of God's knowledge. This desire could only be satisfied by contemplating the king's "marvellously executed" images, for just as the divine knowledge was unreachable to the prophet David, so the real king was inaccessible to ordinary people.

Erznkac'i continues his commentary with a discussion of the archetype and similitude to the archetype. Even being created in God's image and appearance, the prophet was unable to reach God's knowledge because he was not the archetype himself but merely reflected "the likeness of the beauty of the archetype." So it is with the king's image: although marvellously executed, it does not represent but merely imitates the archetype - that is, the king himself. This notion of likeness to and imitation of the archetype is central to Erznkac'i's oratorial works, with his interpretations coming close to both the Platonic and Aristotelian concepts of mimesis. He often describes God as the archetype that can and should be imitated but can never be reached. To explain to his audience the necessity of maintaining likeness to the archetype, Erznkac'i draws frequent comparisons to (royal) artistic images. Among many examples of this, I would like to include in this discussion two passages - one from Sermon 1 and the other from Sermon 8 - which were read by Erznkac'i in Drazark and Sis, respectively. In the latter sermon, while commenting on the parable of the two debtors (Lk. 7:40-50), Erznkac'i says: ${ }^{17}$

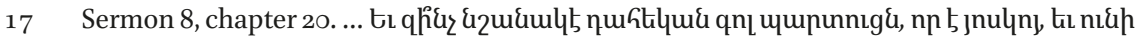

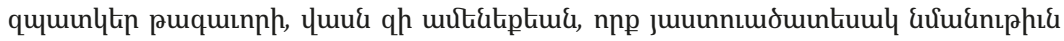

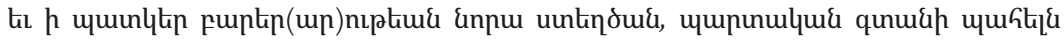
qulqpaumuhi \&ưuinıphı́. Erznkac'i, Speeches and Sermons, p. 134. 
Sermon 8, chapter 20.... And what is the meaning of the coin that is made of gold and possesses the king's image (for all those who are created in deiform likeness and in the munificent image of Him must preserve the likeness of the archetype)?

In Sermon 1, Erznkac'i goes on to explain the necessity of maintaining likeness to the original with reference to the desire and love that one feels towards the person who is portrayed. It is because of this admiration that the artist is eager to reproduce "the form and the likeness of the original" as genuinely as possible:18

Sermon 1, chapter $4 . \ldots$ or, when someone creates the beautiful image of a living rational person and adorns it with royal honour, with the colours of paints and various hues, the form and the likeness of the original are depicted on wood not for completing the imperfection of the living [person], but the likeness of the original are created in beautifully glaring paints in order to satisfy the desires of the heart that feels yearning and love towards the living [person].

The passage's description of figurative painting on wood points to a panel painting tradition - attested in other Armenian texts as well, though no extant examples are known. Erznkac'i shows an interest in artistic issues in many of his other works as well. On one occasion, for instance, he writes about how various craftsmen prepared the king's crown and robes: ${ }^{19}$

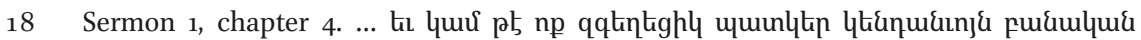

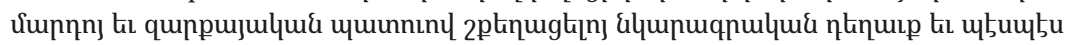

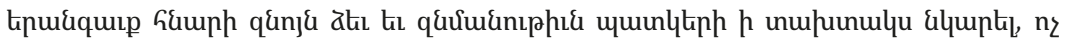

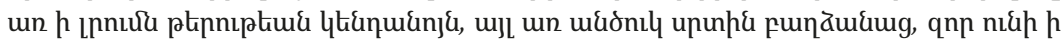

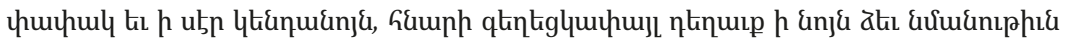
urot.l. Ibid., p. 38.

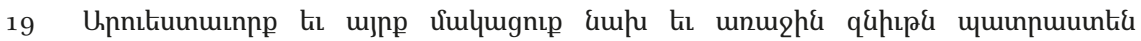

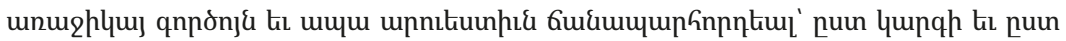

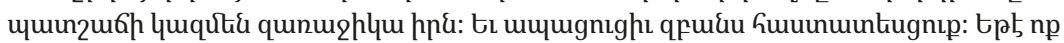

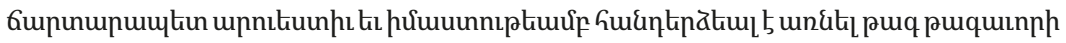

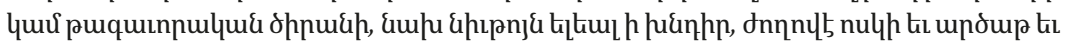

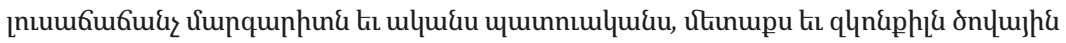

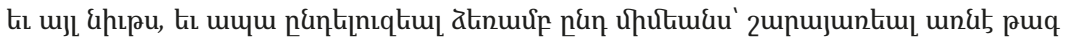

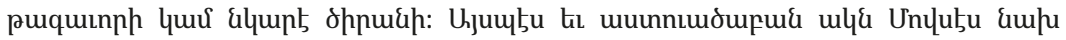

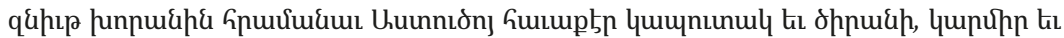

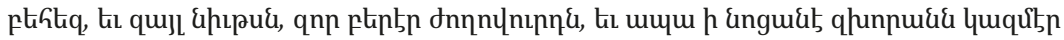
цlujnıptiu\{. Cited in: Srapyan, “Arvesti əmbinumə," p. 131 (M6562, fol. 74r). 
Artists and other connoisseurs first prepare the material for the upcoming work and then, travelling through art, they create the upcoming object in an orderly and appropriate manner. ${ }^{20}$ And let us confirm these words with a demonstration. If a craftsman takes it upon himself to create with art and wisdom a king's crown or a royal cirani, ${ }^{21}$ he first searches for the material, collects gold and silver, beamy pearls and precious stones, silk and the sea conch, ${ }^{22}$ and other materials; and after embroidering these together by hand, he makes the chain(s) of the king's crown or colours the cirani. In the same way, Moses, the eye of the divine word, ${ }^{23}$ by the order of God, first collected the material necessary for the sanctuary blue and purple, scarlet and fine linen, and other materials that people

Cf. St Basil, Hexaemeron (Homily III, chapter 10): "Yet, the artist, even before the combination of the parts knows the beauty of each and approves them individually, directing his judgment to the final aim." See: Saint Basil, Exegetic Homilies, translated by Sister Agnes Clare Way, C.D.P., The Fathers of the Church: A New Translation - vol. 46 (Washington, D.C., 1963), p. 53. In the Armenian version of the Hexaemeron, which was translated from Syriac probably in the 6th century, the quoted sentence reads: "Now the artist, even before he had begun his task, had marked in his mind the complete work of the image." See: Saint Basil of Caesarea and Armenian Cosmology: A Study of the Armenian Version of Saint Bail's Hexaemeron and Its Influence on Medieval Armenian Views about the Cosmos, by Robert W. Thomson, Corpus Scriptorum Christianorum Orientalium 646, Subsidia tomus 130 (Lovanii, 2012), p. 115. Here, as in Erznkac'i's text, the word čartarapet is used for artist/ craftsman.

21 Cirani (dhpulah, pronounced as tzirani) is the name of the red-purple robe worn by Armenian kings. From it derives also the word ciranacin (дppuqumohd, lit. born in the cirani), which is used to refer uniquely to royal birth, equivalent to Greek porfyrogenetos. For the dye used to colour royal ciranis, see the next note.

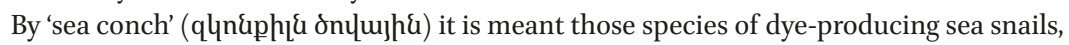
from which the red-purple colour and their nuances were obtained, known as 'Tyrian royal purple,' which was used to colour royal garments in the ancient and medieval Mediterranean, and beyond. In Classical Armenian, the colour obtained from these sea snails was called cirani (red, purple, and/or their various nuances) or covu cirani (sea red, sea purple), which apparently gave its name to Armenian royal robes, called similarly cirani. For the purple dye and various species of dye-producing sea snails, see: Lloyd B. Jensen, "Royal Purple of Tyre," Journal of Near Eastern Studies 22/2 (1963), 104-18. For the meaning and other words deriving from royal cirani (dhpuqu), see: Awetik'ean, Siwrmēlean, and Awgerean, Nor bargirk' haykazean lezui, vol. 1 (Venice, 1836), pp. $1016-7$. For konk'il = conch (lnuphl, also as lnuptin/konk'et, lnuptl/konk'el), see: ibid., p. 1115 . For a general overview of the symbolic use of purple in Armenian culture, see: Boghos Levon Zekiyan, "La Porpora in Armenia: Tra mito, folklore, arte e religiosità: Dall'Inno di Vahagn al Bolo Armeno," in La Porpora: Realtà e immaginario di un colore simbolico, Atti del Convegno di Studio, Venezia, 24-25 ottobre 1996, ed. Oddone Longo (Venice, 1998), pp. $276-97$.

23 Meaning the interpreter of the divine word, the one who is able to see through God's word. 
brought him - and then from these materials he made the tabernacle of the testimony [cf. Ex. 25:1-16].

It becomes clear from what is cited above that the royal artists would have possessed both wisdom and artistic mastery. Indeed, in Erznkac'i's text, the word Gupununumlin ('čartarapet') is used with the meanings of master, architect, craftsman, or artist, who is ingenious and skillful in his creation. ${ }^{24}$ Before undertaking his work, the artist collects with care all the appropriate materials, which Erznkac'i parallels to how Moses collected people's offerings to create the Holy Tabernacle.

\section{Sermon 29, chapter 14}

Sermon 29. [Sermon] of Yohannēs about the deceased in Christ and the mystery of man's creation and death, from the word of the wise man, which says: "God created man incorruptible and made him according to His own munificent image" [Wisdom 2:23]. ${ }^{25}$

Chapter 14. For He first said "image," and then "according to likeness" [cf. Gen. 1:26]. As, for example, those who depict royal and princely images, draw on wood the archetype's beautiful appearance by means of colours in order to transmit to the image the beauty of the

24 For the meanings of 'čartarapet' (Gupunupuuutun) in Classical Armenian, see: Gabriēl Awetik'ean, Xač'atur Siwrmēlean, and Mkrtič' Awgerean, Nor baŕgirk' haykazean lezui [New Dictionary of Armenian Language], vol. 2 (Venice, 1837), p. 176.

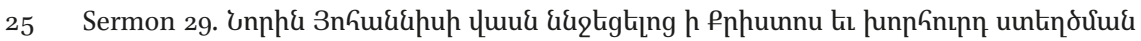

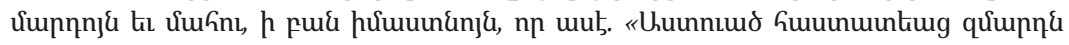

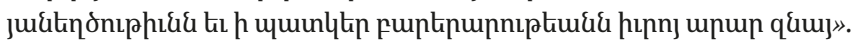

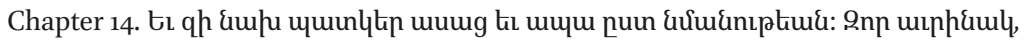

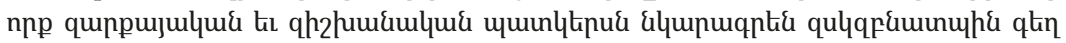

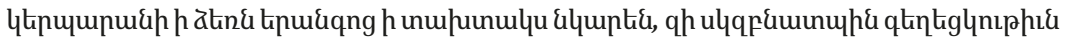

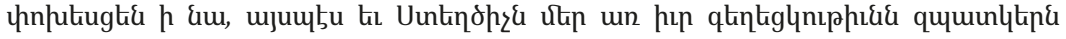

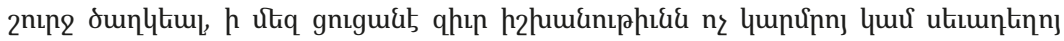

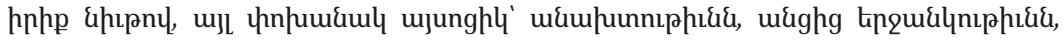

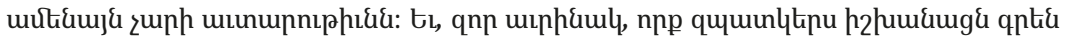

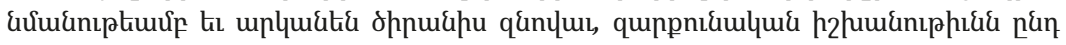

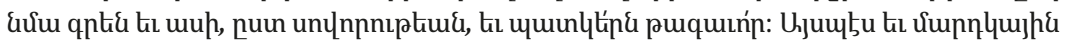

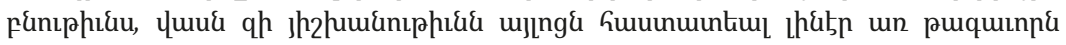

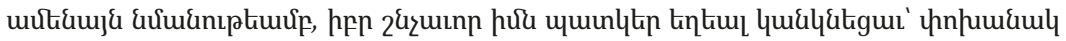

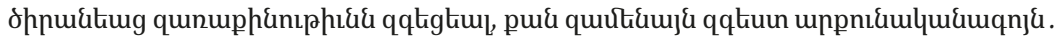

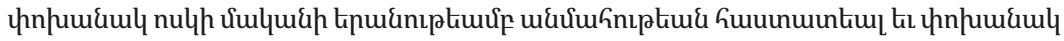

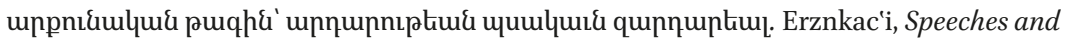
Sermons, pp. 501-19, esp. $5^{\circ}$. 
archetype. Similarly, our Creator painted His beauty into the image, in that way demonstrating to us His power not by means of certain substances of red or black colours but - instead of these - purity, happiness, [and] remoteness from all evil. ${ }^{26}$ As, for example, those who write the images of princes by the likeness and put on them ciranis $^{27}$; they demonstrate by this the royal power, and it is said customarily: "The image [is] the king!" So also with human nature; since it is established

26 Cf. Saint Gregory of Nyssa's On the Creation of Humankind: "Aussi de même que les peintres, dans les couleurs qu'ils emploient pour représenter un personnage sur un tableau, arrangent leurs teintes selon la nature de l'objet pour faire passer dans le portrait la beauté du modèle, imaginez de même celui qui nous façonne : les couleurs en rapport avec sa beauté sont ici les vertus qu'il dépose et fait fleurir en son image pour manifester en nous le pouvoir qui est le sien. La gamme variée des couleurs qui sont en cette image et qui représentent vraiment Dieu n'a rien à voir avec le rouge, le blanc ou quelque mélange de couleurs, avec le noir qui sert à farder les sourcils et les yeux et dont certain dosage relève l'ombre creusée par les traits, ni en général avec ce que les peintres peuventencore inventer. Au lieu de tout cela, songezà la pureté, à la liberté spirituelle, à la béatitude, à l'éloignement de tout mal, et à tout le reste par quoi prend forme en nous la ressemblance avec la Divinité." See: Grégoire de Nysse, La Création de l'homme, introduction et traduction par Jean Laplace, notes par Jean Daniélou, réimpression de la première édition revue et corrigée (Paris, 2002), p. 96-7. In the Armenian version of On the Creation of Human Kind, which was translated in the early 8th century by Step'annos Siwnec'i and Dawit' Hyupatos and which Erznkac'i likely made use of, the

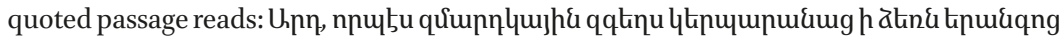

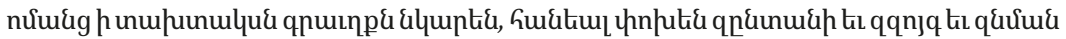

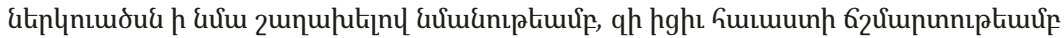

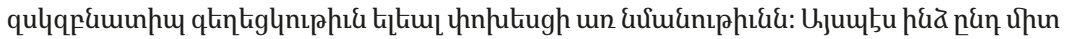

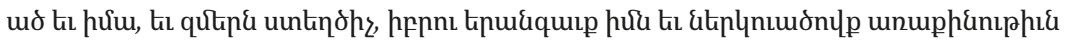

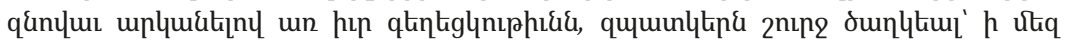

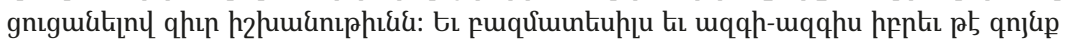

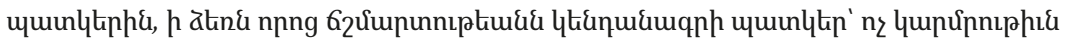

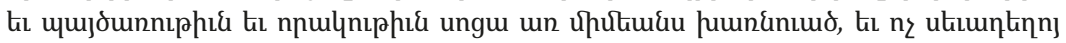

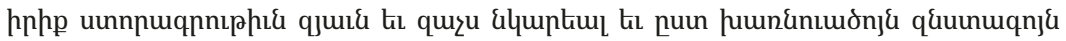

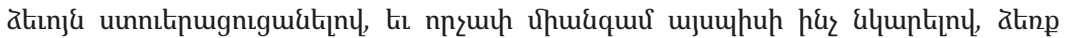

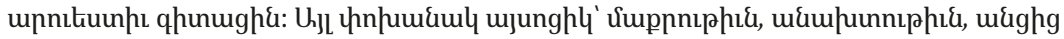

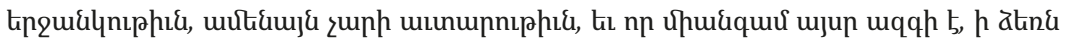

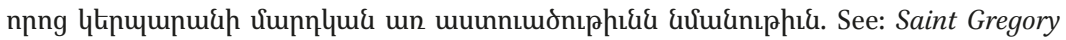
of Nyssa (S. Grigor Niwsacii), Tesut'iwn i mardoyn kazmut'iwn (Yatags kazmut'ean mardoy) [On the Making of Man], critical text with introduction and annotations by Stella Vardanyan (Holy Etchmiadzin, 2008), p. 59-6o (in Armenian). The same passage from Gregory of Nyssa is also cited by John of Damascus in his First Treatise against the iconoclasts: "Just as painters transfer human forms on to tablets by means of certain colors, applying corresponding paints by imitation, so that the beauty of the archetype is transferred with accuracy to the likeness." See: Saint John of Damascus, p. 47.

For cirani see above, notes 21 and 22. 
to rule over others with all likeness to the king, ${ }^{28}$ it was raised up as a living image: instead of being clothed in ciranis, it is clothed in virtue rather than in all garments of kingship; instead of a gold sceptre, it is established with immortal beatitude; and instead of a royal crown, it is adorned with the crown of justice. ${ }^{29}$

28 In developing his discussion on the human capacity to rule over others Erznkac'i could also be inspired by Nemesius of Emesa's treatise On the Human Nature, which was translated into Armenian in the same period as the similar treatise authored by Gregory of Nyssa. See Nemesius of Emesa (Nemesios Emesac'i), Yatags bnut'ean mardoy [On the Nature of Man] in Old Armenian translation, Text, Introduction and Notes by Karine Mosikyan (Yerevan, 2019). For the Armenian translations of these and other patristic texts, see Jean-Pierre Mahé, "L'Arménie et les pères de l'Église: histoire et mode d'emploi (V'-XII siècle)," in La documentation patristique: bilan et prospective, eds. Jean-Claude Fredouille, and René-Michel Roberge (Laval - Paris, 1995), pp. 157-79.

29 This passage is almost entirely inspired by Gregory of Nyssa's On the Creation of Human Kind: "D'après l'usage commun, les auteurs des portraits de princes, en plus de la représentation des traits, expriment la dignité royal par des vêtements de pourpre et devant cette image, on a l'habitude de dire: «le roi ». Ainsi la nature humaine, créée pour dominer le monde, à cause de sa ressemblance avec le Roi Universel, a été faite comme une image vivante qui participe de l'archétype par la dignité et par le nom : la pourpre ne l'entoure pas, un sceptre ou un diadème ne signifient pas sa dignité (l'archétype, lui, n'en a pas); mais, au lieu de pourpre, elle est revêtue de la vertu, le plus royal de tous les vêtements; au lieu d'un sceptre, elle s'appuie sur la bienheureuse immortalité ; au lieu d'un diadème royal, elle porte la couronne de justice, en sorte que tout, en elle, manifeste sa dignité royale, par son exacte ressemblance avec la beauté de l'archétype." See: Grégoire de Nysse, p. 95. Erznkac'i made use of the Armenian translation of On the Creation of Human Kind, in which the quoted

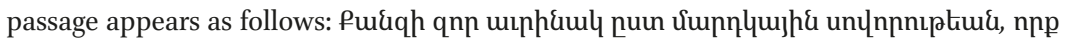

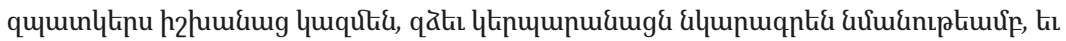

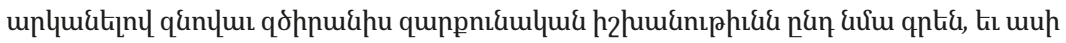

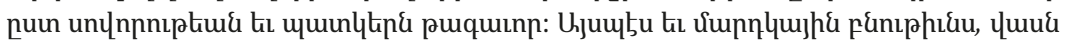

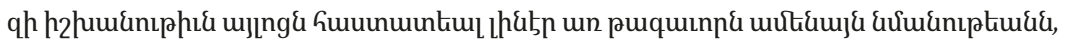

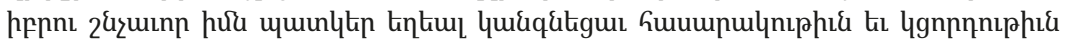

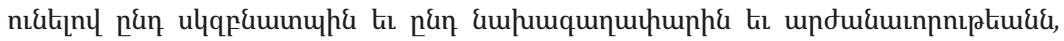

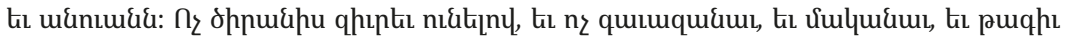

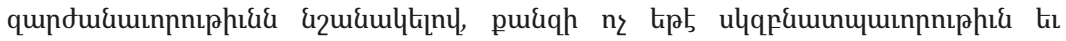

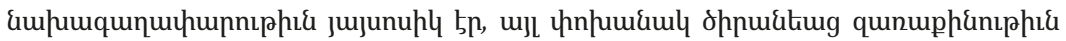

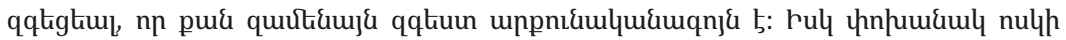

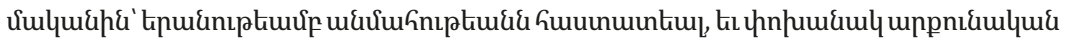

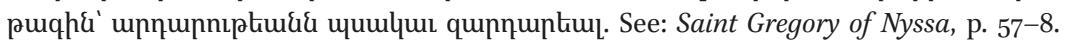
The same passage from Gregory of Nyssa is also cited by John of Damascus in his First Treatise against the iconoclasts: "Just as the custom is that those who fashion images of rulers, as well as expressing their features, express the imperial dignity by garments of purple, and it is customarily called both image and emperor, so too human nature, since it is fashioned to rule everything else, is set up as a kind of living image, participating in its archetype in both dignity and name." See: Saint John of Damascus, p. 47. 
Here again, Erznkac'i implies the concept of the archetype's primacy over the image, starting his chapter with a reference to Gen. 1:26 ("Let us make man in Our image and after Our likeness")..$^{30}$ The artists who depict royal and princely images make use of colours in order to transmit the beauty of the archetype. Paints are, however, material means, and their role is to make the royal image recognizable for viewers, so that the king's image can refer to the king himself ("The image is the king!"). Closely following Gregory of Nyssa, Erznkac'i explains how human beings can exercise their likeness to God and imitate God's power without having attributes of power, such as royal robes, sceptre, or crown; as living images of God, human beings can instead imitate Him through spiritual virtues, such as goodness, beatitude, and justice. Although not explicitly, this analogy points to a disparity between kings and ordinary humans with respect to their capacity to achieve divine likeness. Kings are privileged in their imitation of God not only because they are created in God's image and likeness but also because of their royal status: bestowed with attributes of power upon taking up their royal responsibilities, kings should seek to imitate the Heavenly King and to reign on earth in imitation of Him. Erznkac'i elaborates on this in another sermon chapter, translated next.

\section{Sermon 30, chapter 23}

Sermon 30. Speeches on the Lord's word "I am the good shepherd" [Jn 10:11 and 14] composed by the blessed vardapet Yohannēs E[r]znkayec'i on the request and demand of the valiant vardapet [*the name is missing] [and read] at the door of the Surb Karapet Church. ${ }^{31}$

Chapter 23. And again, by saying "I am the [good] shepherd," He makes it clear that it was He whom the prophets and the righteous took as

30 The primacy of archetype over image is well present in John of Damascus, who similarly uses examples of artistic images. Cf. Saint John of Damascus, p. 95: "Firstly, what is an image? An image is therefore a likeness and pattern and impression of something, showing in itself what is depicted; however, the image is certainly not like the archetype, that is, what is depicted, in every respect - for the image is one thing and what it depicts is another - and certainly a difference is seen between them, since they are not identical. For example, the image of a human being may give expression to the shape of the body, but it does not have the powers of the soul; for it does not live, nor does it think, or give utterance, or feel, or move its members."

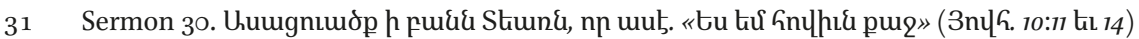

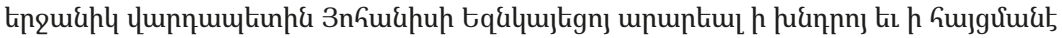

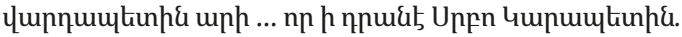

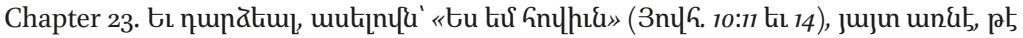

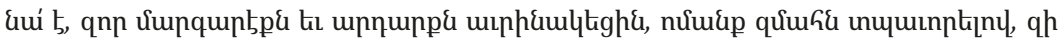


example: some imitated His death - since some of them were put to death - and others lived and reigned [in imitation of Him]. As, for example, a king's image is depicted during his childhood, during his youth, in his old age, and also during his reign; in the same way, all these shepherds, each one in his own time, were images of Christ's appearances [meaning prefigurations of Christ - G.G.S.]. Since the image of the king that is painted in his youth preserves the same likeness of the boyish form, likewise [the one] at full maturity and in old age. And when he accepts the crown, the likeness is similarly kept in each of his images. ${ }^{32}$ In the same way, all the saints are depicted as the image of Christ's pastorship ...

In what follows in chapter 23 are explanations of the ways in which various biblical characters prefigured Christ in their own times. Thus, Abel, who was a shepherd and whose sacrifice was favoured by God, was himself killed by his brother Cain. Or, Jacob, a shepherd too, was persecuted by his brother and then became a shepherd for Laban's flocks - in that way prefiguring Christ, the

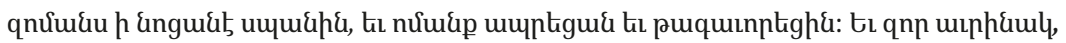

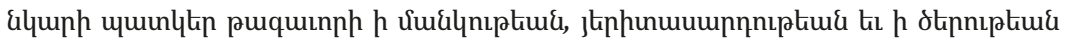

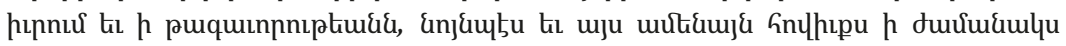

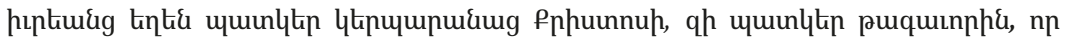

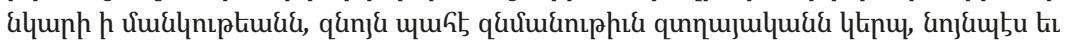

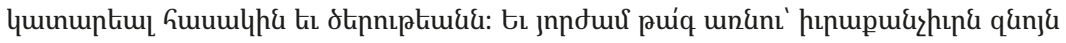

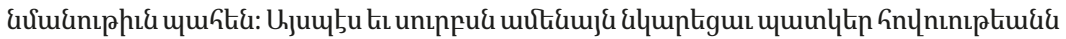
Pnhuunnul ... Erznkac'i, Speeches and Sermons, pp. 520-44, esp. 534. In this edition, the biblical verse "I am the good shepherd" (Jn. 10:11 and 14) that appears in the title of Sermon 30 is mentioned in reference to 1 Cor. 12:28. This must be an accidental editorial mistake, for elsewhere in the book the same verse appears with the correct biblical reference.

The necessity of keeping the likeness in accordance with the form, which Erznkac'i mentions on this and other occasions, could be inspired, among others, by Saint Basil the Great, who mentions it in his On the Holy Spirit (chapter 18:45): "and as in works of art the likeness is dependent on the form, so in the case of the divine and uncompounded nature the union consists in the communion of the Godhead." See: The Treatise de Spiritu Sancto, the Nine Homilies of the Hexaemeron and the Letters of Saint Basil the Great, Archbishop of Caesarea, translated with notes by the Rev. Blomfield Jackson (Michigan, 1975), p. 28. John of Damascus, when citing Basil's words, formulates it as follows: "And just as with works of art the likeness is in accordance with the form, so with the divine and incomposite nature the union is in the communion of the divinity." See: Saint John of Damascus, p. 42. It should be however noted that the Armenian translation of the On the Holy Spirit considerably differs from the Greek version. See Yakob K'eosēean, "S. Barseł Kesarac'u Surb Hogun nuiruac čari hayerēn t'argmanut'iwnə," [The Armenian Translation of St. Basil of Caesarea's Homily on the Holy Spirit] Ganjasar 4 (1993), 165-214, 5 (1994), 201-240. The treatise On the Holy Spirit was known to Armenian authors also through the Refutation of the Council of Chalcedon by Timothy Aelurus, which contains excerpts from it. 
shepherd of the Jews, who was persecuted by Herod, becoming the shepherd for the pagans.

Just as Christ was prefigured by various Old Testament shepherds, so too a king - as the archetype - should be recorded in likenesses from various moments of his life. ${ }^{33}$ In this sermon chapter, Erznkac'i's biblical commentary emerges as a source of information regarding medieval practices of royal portraiture. As attested in Sermon 30 and preserved in illuminated manuscripts, a king could indeed be portrayed at several different ages: long before his enthronement, at his coronation, and as the reigning king. A fortunate extant case is the series of images of King Lewon II, which support and provide material witness to Erznkac'i's account. Chronologically, the first surviving image of Lewon represents him as a young prince and was likely produced on the occasion of his knighting ceremony which took place in 1256 (Figure. 1.1). The next image of the future king is to be found in a richly illustrated Gospel manuscript, created in 1262 on the occasion of his marriage to the lady Keran (Figure. 1.2). The third and fourth images, both executed in the 127os, represent the newly enthroned king. In one miniature, he is depicted together with his family, asking for divine intercession (Figure. 1.3), and in the other, he is kneeling and praying in front of the Eucharistic table (Figure. 1.4). Probably, it is also Lewon II whose representation is meant in the royal images inserted into a marginal ornament of the Lectionary of Crown Prince Het'um (Figure. 1.5) - an important royal manuscript that was created for his son and successor Het'um in 1286, three years before Lewon's death.

Whether Erznkac'i ever saw these or other images of Cilician kings must remain a matter of speculation. However, a reconstruction of certain circumstances may make this suggestion less hypothetical. As noted in the introduction to this article, Erznkac'i spent the last phase of his life in Cilicia and died in Akner, which was one of the most significant monastic centres, closely connected with the royal family. It was to this monastery that Queen Keran offered the sumptuous Gospel manuscript she had commissioned in 1272 - now widely known as the Queen Keran Gospels (J2563) $\cdot{ }^{34}$ Erznkac'i, who was greatly interested in art and was in contact with King Lewon II, likely saw this manuscript, which also features a miniature of the royal family (Figure. 1.3).

33 It is useless to say that by 'likeness' he does not mean physiognomic likeness.

34 See the manuscript's principal colophon (folio 273v) reproduced in: Hayeren jeragreri hišatakaranner, $\check{Z} G$ dar [Colophons of Armenian Manuscripts, 13th Century], ed. Artašes Mat'evosyan (Yerevan, 1984), p. 416. 


\section{Conclusion}

Yovhannēs Pluz Erznkac'i is one of the key authors whose works offer us precious glimpses into the spiritual culture and aesthetic thinking of 13th-century Armenia. The few excerpts chosen for translation here reveal this significance with regard to two specific subjects - urban celebrations and royal images. Erznkac'i approaches the first subject from a broad social perspective, allowing us to explore the ways in which commoners could partake in the urban feasts organized on the occasion of a king's enthronement. Looking through the eyes of a guest, Erznkac'i narrates this tradition with intriguing details which, because of their commonness, would have gone unnoticed by local Cilician authors, most of whom had courtly or pro-courtly origins.

The second subject, concerning artistic images, is far more intensely present in Erznkac'i's writings. His remarks, emphasizing the aesthetics and reception of painted images, are evocative in helping to understand the philosophical and theological grounds of artistic productions. Thus, the practice of fashioning a king's image "in deiform likeness" (Sermon 8, ch. 20) is attested by contemporary royal images (cf. images of King Lewon and Christ in Figure. 1.3) that Erznkac'i may have had the opportunity to contemplate personally in the milieu of the court of King Lewon II. Also evident in these visual sources is the tradition of depicting the king at different moments of his life, which Erznkac'i invokes for comparative and exegetical purposes (Sermon 30, ch. 23).

The selected excerpts reflect a non-conflicting combination of the Platonic and Aristotelian concepts of mimesis, something Erznkac'i inherited from patristic works, sometimes following the Church Fathers verbatim, as in the case of Gregory of Nyssa. Although the king's images should properly reflect his royal appearance and should be "executed marvellously," still, they can never replace the king in person, for they are merely reflections of the king (it is in this context of the archetype's primacy that Erznkac'i's expression "the beauty of the archetype" should be understood - an expression rooted in the works of the previous authors he consulted). In this sense, the use of the concept of mimesis is Platonic, which insisted that imitation is inferior to archetype and cannot replace it by representation. However, in most of the instances in which Erznkac'i applies the concept of the archetype and its image - even though in a derivative way, the principal aim is not so much to underscore the inferiority of the artistic production compared to its living original, but to highlight the potential of the image which is capable of partially replacing the archetype and therefore offering the possibility of approaching it. This positive and didactic use of mimesis is closer to the Aristotelian understanding of imitation and can also be favourably situated within the spiritual currents of the 
Armenian society for whom Erznkac'i's homilies were composed. In conclusion, I would therefore like to focus not so much on the intellectual repertoire of this Armenian polymath of the 13th century but on the moral-spiritual and socio-political messages that he tried to transmit through his public speeches.

The frequent evocation of artistic portraiture in Erznkac'i's exegetical preaching served to explain one of the principal tenets of medieval Christian piety - the imitation of God - whereby the believer, being created in God's image and likeness (Gen. 1:26), could achieve the fulfilment of the divine image by conducting himself in imitation of God. The audience for whom Erznkac'i's speeches were delivered was constantly reminded that the state ruler exemplifies the ideal imitation of God and that each member of society is likewise able to exercise his or her likeness to God by employing their spiritual virtues and their capacity to rule over other creatures.

\section{Acknowledgements}

Research for this paper was carried out in the framework of the project "Royal Epiphanies: The King's Body as Image and Its Mise-en-scène in the Medieval Mediterranean (12th-14th Centuries)," funded by the Swiss National Science Foundation (project $\mathrm{n}^{\mathrm{o}} 173 \mathrm{O} 45$, University of Fribourg, Switzerland). I would like to sincerely thank Jesse S. Arlen for his careful reading of the first draft of this article.

\section{Bibliography}

\section{Primary Sources}

Baghdasaryan, Edvard, Hovhannes Erznkac'in yev nra xratakan arjako [Hovhannes Erznkac'i and His Advice Literature] (Yerevan, 1977).

Baghdasaryan, Edvard, and Aramean, Mesrop, "Yovhannēs Erznkac'u I ČX satmosn čaṙə," [Yovhannēs Erznkac'i's Sermon On Psalm 140] Gandzasar 7 (2002), 384-408.

Der Nersessian, Sirarpie, "Une apologie des images du septième siècle," Byzantion 17 (1944-1945), 58-87. Reprinted in her Études byzantines et arméniennes / Byzantine and Armenian Studies, tome I (Louvain, 1973), pp. 379-403.

Hayeren jeragreri hišatakaranner, ŽG dar [Colophons of Armenian Manuscripts, 13th Century], ed. Artašes Mat'evosyan (Yerevan, 1984).

K'eosēean, Yakob, "S. Barseł Kesarac'u Surb Hogun nuiruac č'ari hayerēn t'argmanut'iwnə," [The Armenian Translation of St. Basil of Caesarea's Homily on the Holy Spirit] Ganjasar 4 (1993), 165-214, 5 (1994), 201-240. 
Nemesius of Emesa (Nemesios Emesac'i), Yatags bnut'ean mardoy [On the Nature of Man in Old Armenian translation], text, introduction and notes by Karine Mosikyan (Yerevan, 2019) (in Armenian).

(Saint Basil) The Treatise de Spiritu Sancto, the Nine Homilies of the Hexaemeron and the Letters of Saint Basil the Great, Archbishop of Caesarea, translated with notes by the Rev. Blomfield Jackson (Michigan, 1975) (orig. publ. 1895).

Saint Basil, Exegetic Homilies, translated by Sister Agnes Clare Way, C.D.P., The Fathers of the Church: A New Translation - vol. 46 (Washington, D.C., 1963).

Saint Basil of Caesarea and Armenian Cosmology: A Study of the Armenian Version of Saint Bail's Hexaemeron and Its Influence on Medieval Armenian Views about the Cosmos, by Robert W. Thomson, Corpus Scriptorum Christianorum Orientalium 646, Subsidia tomus 130 (Lovanii, 2012).

(Saint) Grégoire de Nysse, La Création de l'homme, introduction et traduction par Jean Laplace, notes par Jean Daniélou, réimpression de la première édition revue et corrigée (Paris, 2002).

Saint Gregory of Nyssa (S. Grigor Niwsac'i), Tesut'iwn i mardoyn kazmut'iwn (Yatags kazmut'ean mardoy) [On the Making of Man], critical text with introduction and annotations by Stella Vardanyan (Holy Etchmiadzin, 2008) (in Armenian).

Saint John of Damascus, Three Treatises on the Divine Images, translation and introduction by Andrew Louth (New York, 2003).

Yovhannēs Erznkac'i (Hovhannes Yerzynkatsi), Matenagrut'iwn, hator A. Čarer ew k'arozner [Works, volume I - Speeches and Sermons], eds. Armenuhi YerzynkatsiTer-Srapian, and Edvard Baghdasaryan (Yerevan, 2013).

\section{Secondary Sources}

Awetik'ean, Gabriēl, Siwrmēlean, Xač’atur, and Awgerean, Mkrtič', Nor bargirk' haykazean lezui [New Dictionary of Armenian Language], 2 vols (Venice, 1836-7).

Baghdasaryan, Edvard, "Hovhannes Erznkac'in arvesti u azgagrut'yan masin," [Yovhannēs Erznkac'i on Art and Ethnography] Lraber hasarakakan gitut'yunneri [Herald of the Social Sciences / Armenian National Academy of Sciences] 9 (1971), 75-81.

Baghdasaryan, Edvard, "Hovhannes Erznkac'in Kilikiayi zinvorakan kazmakerput'yunneri masin," [Yovhannēs Erznkac'i on the Military Organizations of Cilicia] Banber Matenadarani [Bulletin of Matenadaran] 16 (1994), 44-57.

Cowe, Peter, S., "Theology of Kingship in 13th-Century Armenian Cilicia," Hask hayagitakan taregirk' [Hask Armenological Yearbook] 11 (2007-2008), 417-30.

Dadoyan, Seta, B., "Yovhannēs Erznkac'i Bluz," in Christian-Muslim Relations: A Bibliographical History, 4 (1200-1350), eds. David Thomas, and Alex Mallett (Leiden, 2012), pp. 572-8.

Der Nersessian, Sirarpie, Miniature Painting in the Armenian Kingdom of Cilicia from the Twelfth to the Fourteenth Century, vol. 1 (Washington, D.C., 1993). 
Ervine, Roberta, "Yovhannēs Erznkac'i Pluz's Compilation of Commentary on Grammar as a Starting Point for the Study of Medieval Grammars," in New Approaches to Medieval Armenian Language and Literature, ed. Jos Johannes Sicco Weitenberg (Amsterdam, 1995), pp. 149-66.

Jensen, Lloyd, B., "Royal Purple of Tyre," Journal of Near Eastern Studies 22/2 (1963), 104-18.

Mahé, Jean-Pierre, "L'Arménie et les pères de l'Église: histoire et mode d'emploi (VeXII ${ }^{\mathrm{e}}$ siècle)," in La documentation patristique: bilan et prospective, eds. Jean-Claude Fredouille, and René-Michel Roberge (Laval - Paris, 1995), pp. 157-79.

Srapyan, Armenuhi, "Hovhannes Erznkac'u gełagitakan hayac'k'nerə," [Yovhannēs Erznkac'i's Aesthetic Thoughts] Patma-Banasirakan handes [Historical-Philological Journal] 3 (1985), 96-107.

Srapyan, Armenuhi, “Arvesti əmbinumə Hovhannes Erznkac'u gorcerum," [The Perception of Art in Yovhannēs Erznkac'i's Works] Banber Erewani hamalsarani [Bulletin of Yerevan University] 2/65 (1988), 127-41.

Srapyan, Armenuhi, Hovhannes Erznkac'i Pluz: Kyank's ew gorca [The Life and Work of Hohannes Erznkac'i Pluz] (Yerevan, 1993).

Xačikyan, Lewon, "Hay arvesti patmut'yan karewor skzbnałbyurnerə," [Important Primary Sources for Armenian Art History] in The Second International Symposium on Armenian Art, Yerevan, 12-18 September 1978, Collection of Reports, 4 (Yerevan, 1981), pp. 39-50.

Zekiyan, Boghos, Levon, "La Porpora in Armenia: Tra mito, folklore, arte e religiosità: Dall'Inno di Vahagn al Bolo Armeno," in La Porpora: Realtà e immaginario di un colore simbolico, Atti del Convegno di Studio, Venezia, 24-25 ottobre 1996, ed. Oddone Longo (Venice, 1998), pp. 276-97. 


\section{Illustrations}

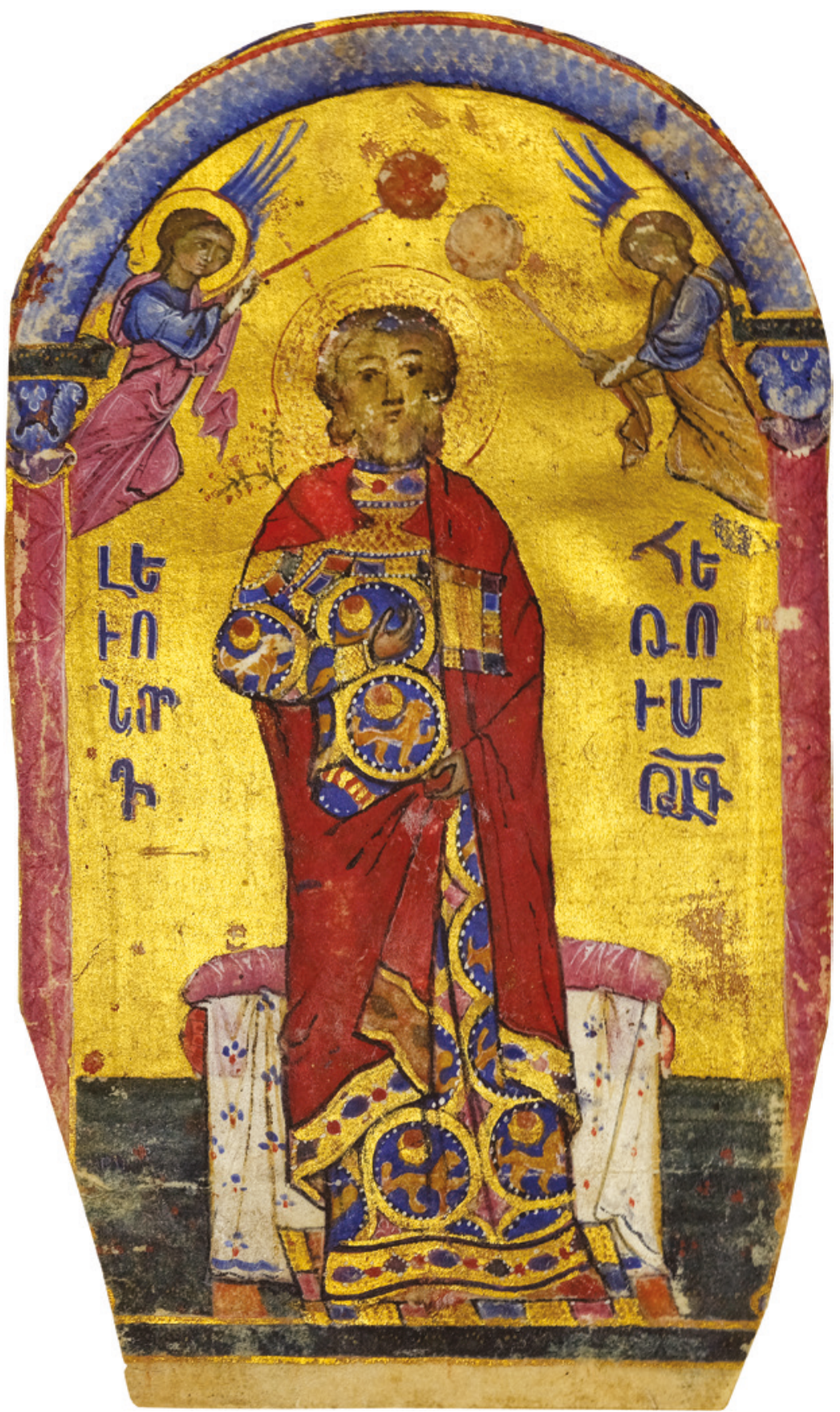

FIGURE 1.1 Prince Lewon, Gospel manuscript (c. 1256?), M8321, fol. 15r

MATENADARAN INSTITUTE OF ANCIENT MANUSCRIPTS, YEREVAN.

PHOTOGRAPH BY HRAIR HAWK KHATCHERIAN 


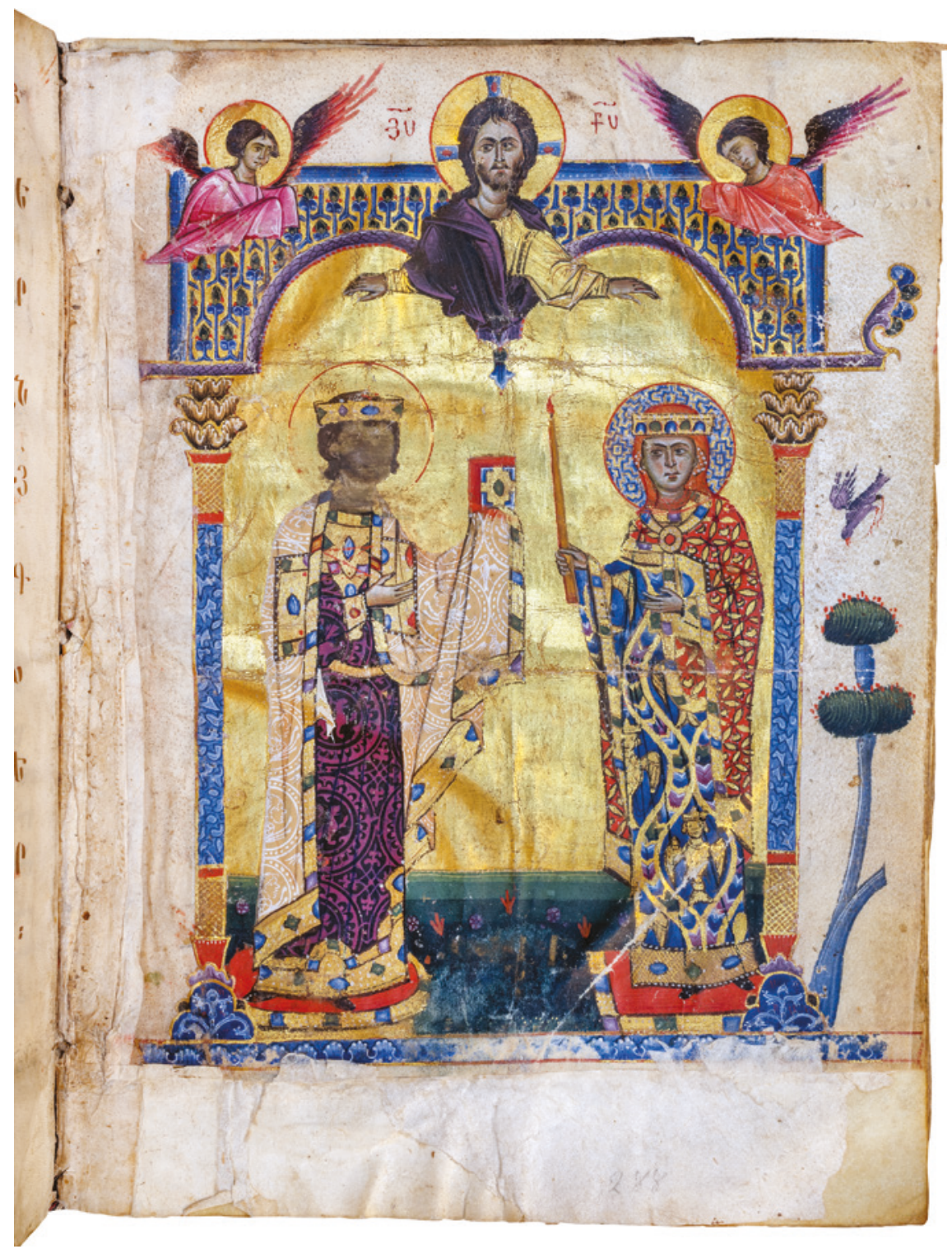

FIGURE 1.2 Prince Lewon and lady Keran, Gospel manuscript (1262), J266o, fol. 288r MANUSCRIPT LIBRARY OF THE ARMENIAN PATRIARCHATE, JERUSALEM. PHOTOGRAPH BY HRAIR HAWK KHATCHERIAN 


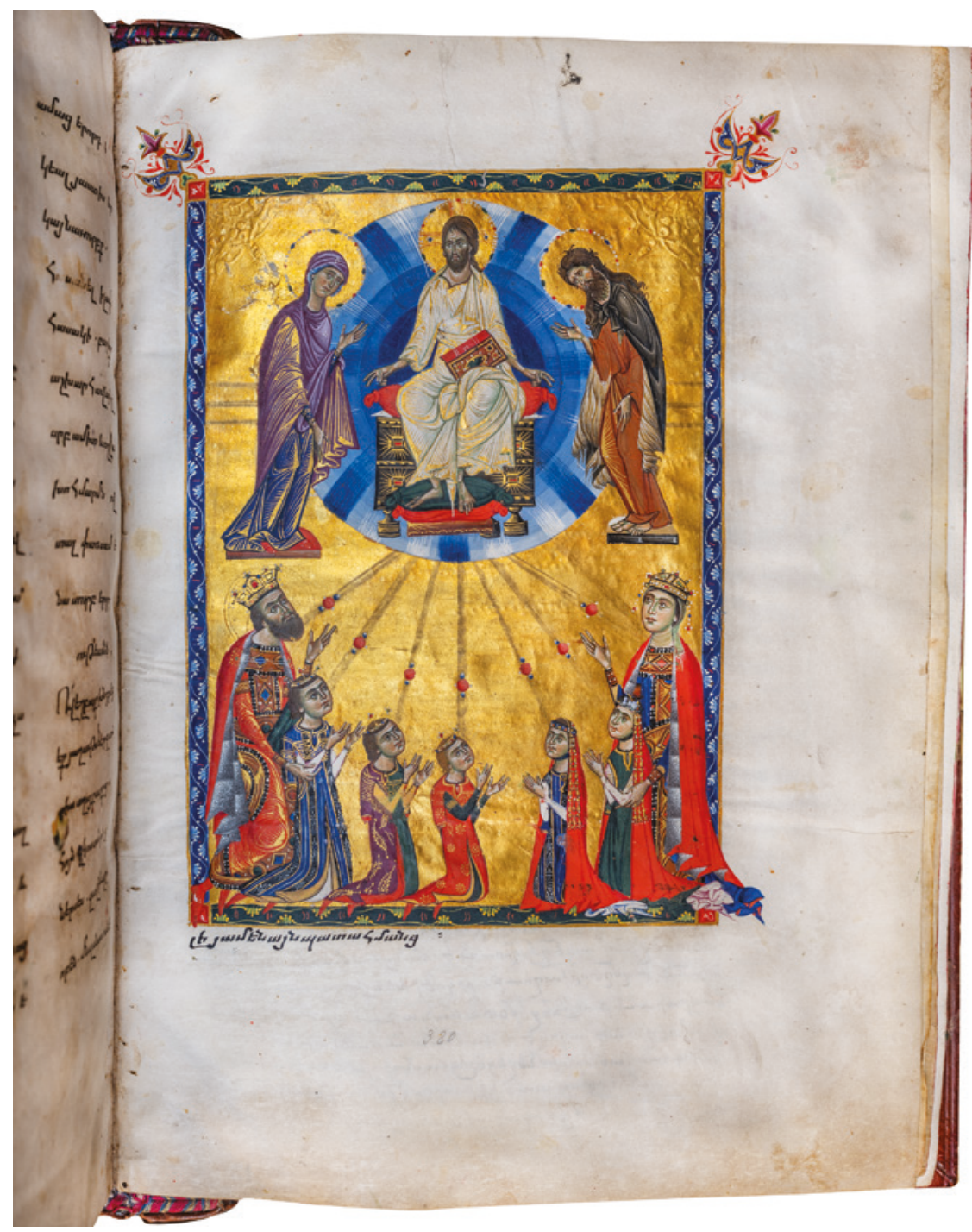

FIGURE 1.3 King Lewon II and queen Keran with their children, Gospel of Queen Keran (1272), J 2563 , fol. 38 or MANUSCRIPT LIBRARY OF THE ARMENIAN PATRIARCHATE, JERUSALEM. PHOTOGRAPH BY HRAIR HAWK KHATCHERIAN 


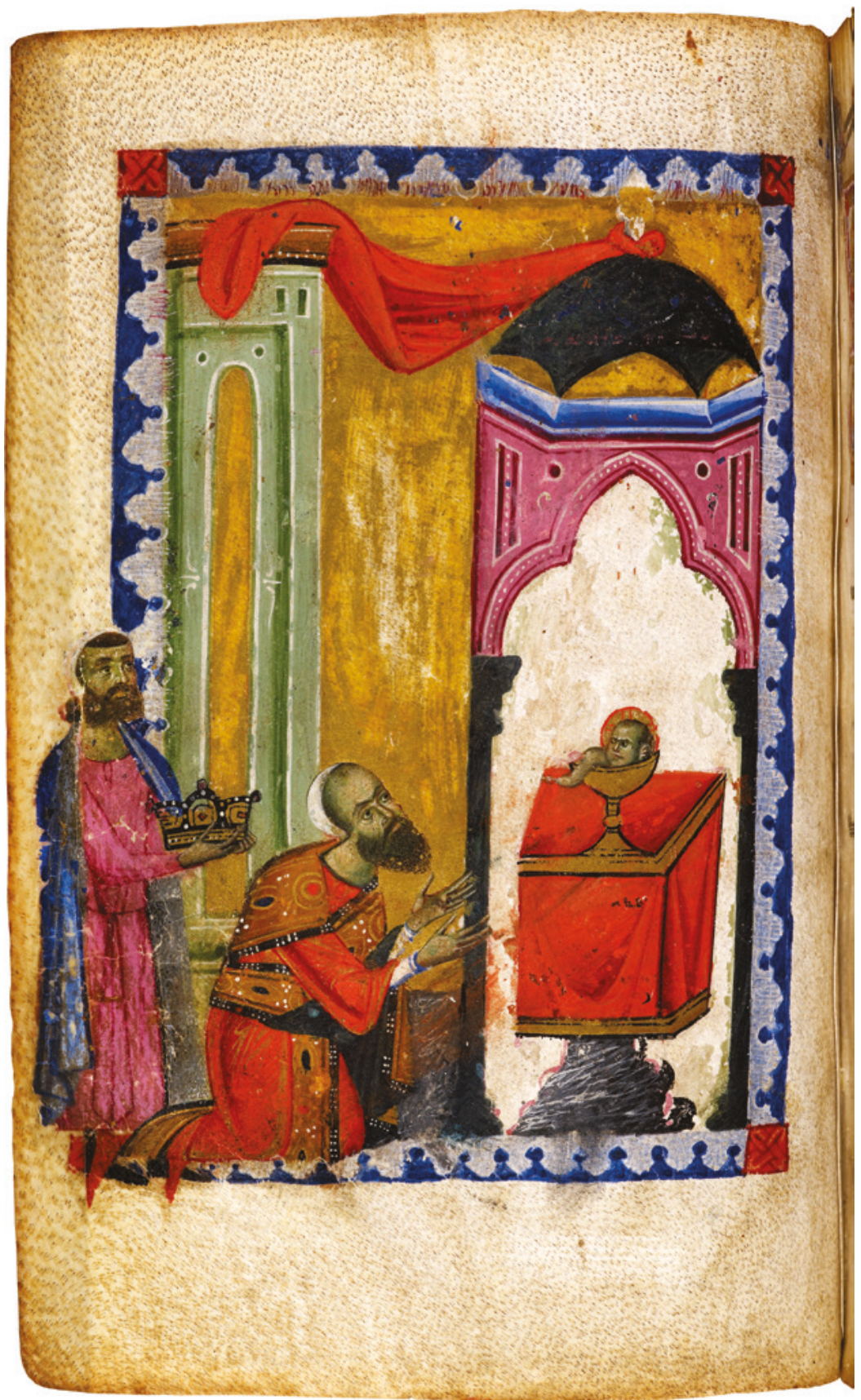

FIGURE 1.4 King Lewon II in front of the Eucharistic table, Breviary of King Lewon (1270s), Or.13993, fol. 9v

BRITISH LIBRARY, LONDON 


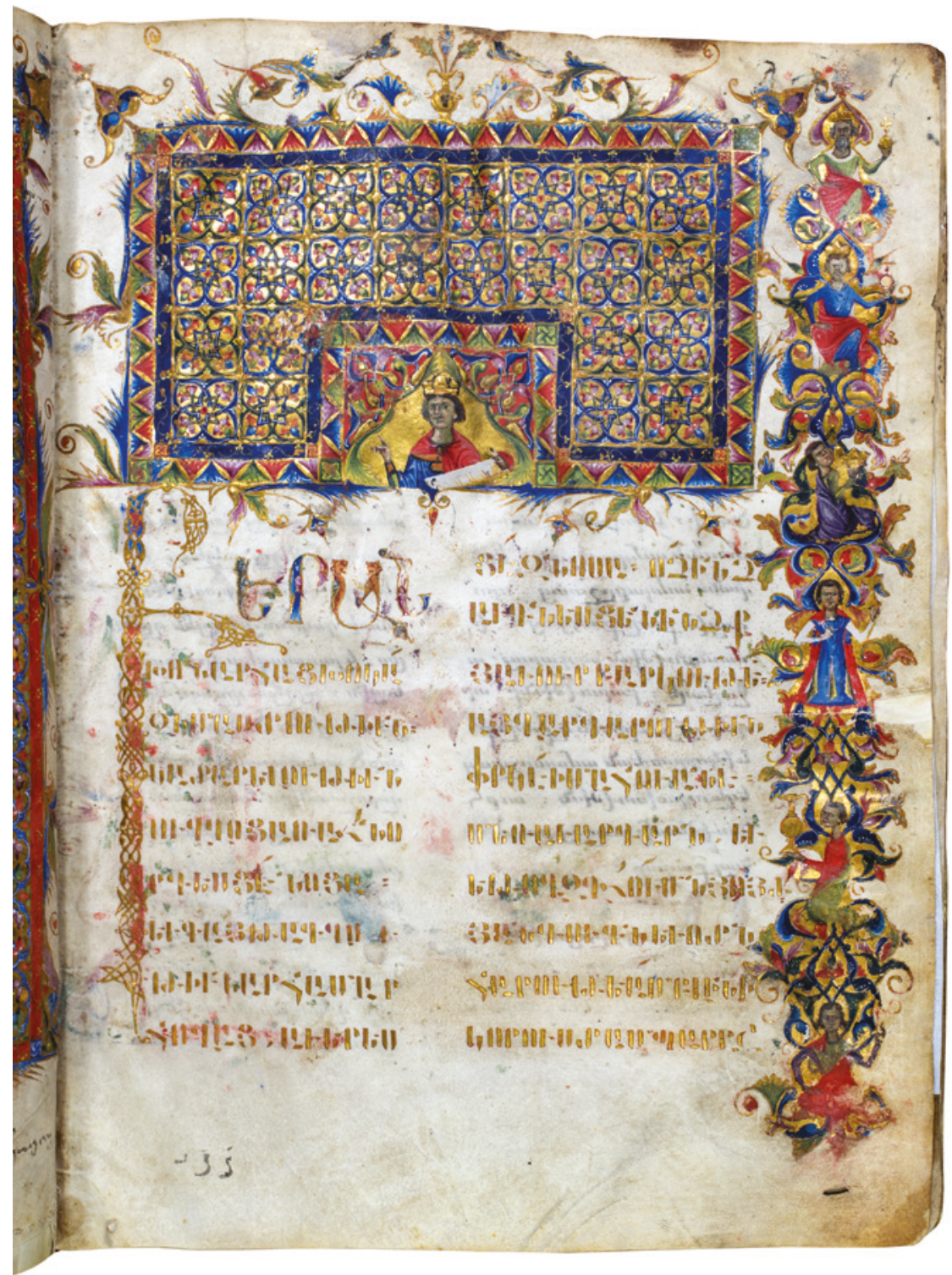

FIgURE 1.5 Lectionary of Prince Het'um (1286), M979, fol. 7r MATENADARAN INSTITUTE OF ANCIENT MANUSCRIPTS, YEREVAN. PHOTOGRAPH BY HRAIR HAWK KHATCHERIAN 